\title{
COMMENTS
}

\section{WHAT'S THE BID DEAL? GAN THE GRAND CENTRAL BUSINESS IMPROVEMENT DISTRICT SERVE A SPEGIAL LIMITED PURPOSE?}

\section{DANIEL R. GARODNICK ${ }^{\dagger}$}

\section{INTRODUCTION}

Business Improvement Districts ("BIDs") have changed the landscape of urban governance. Clothed with limited powers traditionally held by the state, BIDs are private entities that provide supplemental sanitation, security, and social services to limited geographic areas within cities.' Today, BID workers are a regular presence on the municipal terrain-whether they are sweeping streets, hailing taxis, or providing tourist information. BIDs have harnessed private sector creativity to solve complex municipal problems and have made cities safer and cleaner. ${ }^{2}$

Funded by an extra assessment on property owners, BIDs conduct their operations with an efficiency that eludes city bureaucraciesthey are flexible, nimble, and directly accountable to the local businesses that pay for the bulk of their operations. Yet, questions of constitutionality exist when a BID, exercising limited governmental powers, is managed by a board of directors elected through a process that weighs votes in proportion to the value of land owned and

† B.A. 1994, Dartmouth College;J.D. Candidate 2000, University of Pennsylvania. I wish to thank Dean Michael Fitts and Professor Seth Kreimer for their suggestions on an earlier draft. Special thanks to Andrew Morton and Maryann Surrick for their constant feedback and support, to my parents for their life-long guidance and encouragement, and to Dean Janice Austin for taking a chance. I would like to acknowledge the editors of the University of Pennsylvania Law Review for their diligence and professionalism on this piece, and all others throughout the year.

'See GeORge L. KeIIING \& CATHERINE M. ColEs, FIXING BROKEN Windows: RESTORING ORDER AND REDUCING CRIME IN OUR COMMUNITIES 113 (1996) (providing an overview of BID functions).

2 See Heather MacDonald, BIDs Really Work, CITY J, Spring 1996, at 29, 32 (explaining that BIDs have made municipal areas safer and cleaner than they have been in decades). 
guarantees that property owners will always comprise a majority of the board.

Such questions were posed in a recent Second Circuit case, Kessler v. Grand Central District Management Ass'n, in which non-propertyowning citizens residing in a BID challenged the voting structure for electing members of its board. ${ }^{3}$ Disempowered from fully participating in the BID's management, the Kessler plaintiffs argued that a governmental scheme that weighed the votes of property owners more heavily than residents violated the constitutional guarantee of "one person, one vote." As problematic as such a voting structure could be, the success of BIDs and other special purpose districts arises from their efficiency in providing services-efficiency that exists only at the price of subjugating traditional notions of equality.

Nowhere have these questions been debated more fiercely than in New York City, which is home to the largest concentration of BIDs in the United States. ${ }^{5}$ Following an introduction to the BID concept in Part I, Part II of this Comment discusses the nature of New York's most prominent BID and the subject of the Kessler case: the Grand Central Partnership ("GCP"). Part III addresses the Supreme Court's treatment of the "one person, one vote" principle ${ }^{6}$ and its application to local and special purpose districts. Part IV examines the Kessler challenge itself, exposing flaws in both the District Court's and the Second Circuit's analyses. Finally, this Comment will demonstrate through hypothetical examples that BIDs actually may create inefficiencies because property owners and residents may not have matching incentives for the provision of public goods.

s 158 F.3d 92 (2d Cir. 1998).

4 See Thomas J. Lueck, Apartment Owmers Challenging Business District, N.Y. TIMES, Nov. 29, 1995, at B1 (reporting the filing of the Kessler suit on behalf of co-op owners and apartment lessees). The one person, one vote principle was first articulated in Reynolds $v$. Sims, 377 U.S. 533, 568 (1964) (holding that legislative plans to apportion seats in the Alabama legislature in a manner not based on population violated the Fourteenth Amendment's guarantee of equal protection).

${ }^{5}$ See Thomas J. Lueck, Business Districts Grow at Price of Accountability, N.Y. TIMES, Nov. 20, 1994, at Al (explaining that BIDs' "greatest impact has been in New York, where their numbers, size and financial clout dwarf those of BID's in other cities"); MacDonald, supra note 2, at 30 (noting that in 1996, New York City had 34 BIDs "with up to 39 more in the wings").

${ }^{6}$ See Reynolds, 377 U.S. at 565 ("Full and effective participation by all citizens in state government requires, therefore, that each citizen have an equally effective voice in the election of members of his state legislature."). 


\section{BUSINESS IMPROVEMENT DISTRICTS}

\section{A. What Is a BD?}

BIDs are territorial subdivisions within a city in which all property owners or businesses are subject to additional tax assessments ${ }^{7}$ that are used to fund services and improvements within the district. ${ }^{8}$ Services provided by BIDs are directed at improving the quality of life within the BID's territory, and may include garbage collection, street maintenance, security patrols, and even limited social services.'

Developed from the concept of "special purpose districts," BIDs were created by state legislatures to remedy particular public policy challenges that traditional governmental institutions either were incapable of attacking or were simply unwilling to address. ${ }^{10}$ While such districts historically have been limited in scope, they have resolved civic problems, such as water storage ${ }^{11}$ and agricultural improvements and power, ${ }^{12}$ that affect certain individuals more than others. The enabling statutes of the districts generally allowed them to operate on a special, limited basis, while restricting the vote for the district's management to those who were disproportionately affected. ${ }^{13}$ Unlike BIDs, special purpose districts typically did not address broad munici-

' In New York City, BID assessments run at the rate of 15 to 23 cents per square foot; real estate taxes in the city can reach eight to ten dollars per square foot. See New York City Benefits from Private Sector Participation, PUBLIC WORKS, Mar. 1, 1999, at 52.

${ }^{8}$ See Richard Briffault, A Government for Our Time? Business Improvement Districts and Utban Governance, 99 CoLUM. L. REV. 365, 368-69 (1999) (outlining the common features of BIDs).

${ }^{9}$ See id. at 369-70 (listing the typical services provided by BIDs); see also KeLLING \& COLES, supra note 1 , at 113 (discussing the efforts made by BIDs to improve the quality of life within a city district).

${ }^{10}$ See, e.g., Salyer Land Co. v. Tulare Lake Basin Water Storage Dist., 410 U.S. 719, 722 (1973) (" $[\mathrm{F}]$ or less costly projects which would benefit a more restricted geographic area, the State was frequently either unable or unwilling to pledge its credit or its resources.").

"See id. at 726-33 (holding that limiting voting in elections for directors of a water storage district exclusively to landowners represented an exception to the "one person, one vote" rule because of its "special limited purpose" and "disproportionate effect ... on landowners," and did not violate the Equal Protection Clause).

${ }^{12}$ See Ball v. James, 451 U.S. 355, 370-71 (1981) (holding that a plan to limit the vote for directors of an agricultural improvement and power district to landowners was, as in Salyer, constitutional under the exception to the "one person, one vote" principle).

${ }^{13}$ See Ball, 451 U.S. at 370-71 (explaining that activities of the agricultural improvement district had a disproportionate effect on the class of people whom the system made eligible to vote); Salyer, 410 U.S. at 723 (limiting the vote to 77 landowners who would be disproportionately affected by the actions of the water storage district). 
pal problems nor provide police or social services.

BIDs have grown to serve an essential function in municipal governance for several reasons. First, they successfully harness private sector creativity for the purpose of beautifying and securing large geographic areas in cities. ${ }^{14}$ Second, they bring "government" one step closer to the people, so much so that business leaders often call their BIDs rather than their City Council officials for solutions to municipal problems. ${ }^{15}$ Third, they appeal to many commercial merchants because they solve the nagging "free rider" problem, ${ }^{16}$ whereby only some merchants foot the bill for local innovations, but all reap the resulting benefit of the improvements. ${ }^{17}$ BIDs also ensure that all property owners in the area are locked into a payment scheme. ${ }^{18} \mathrm{Fi}$ nally, limiting the vote to property owners ensures that revenues raised will be reserved for the particular programs desired by those most heavily burdened by the tax. ${ }^{19}$

BIDs are structured so that all commercial, industrial, and residential property may be subject to a tax assessment in proportion to the valuation of the property. ${ }^{20}$ A city agency collects the tax and dis-

${ }^{14}$ See MacDonald, supra note 2, at 32 (noting how BIDs effectively brought "to public spaces the techniques of 'common space management' that made malls and office parks so successful").

${ }^{15}$ See Interview with Andrew Manshel, former general counsel and assistant secretary of the board of directors of the Grand Central Partnership, in New York, N.Y. (Jan. 5 , 1999) [hereinafter Manshel Interview] (claiming that BIDs are more responsive to local problems); see also MacDonald, supra note 2, at 41 ("The BID becomes a watchdog for service delivery because it is so close to the ground.").

${ }^{16}$ See Robert CoOter \& Thomas Ulen, LAW AND ECONOMics 107 (3d ed. 2000) (explaining that whenever public benefits are paid for voluntarily, the possibility exists that some will "free ride," or receive the benefits purchased by others without paying for them).

${ }^{17}$ See Briffault, supra note 8 , at 369 (noting that the free rider problem "plagues the efforts of chambers of commerce and merchants' associations to' raise funds to pay for services for their areas," because those payments are voluntary); see also MacDonald, supra note 2, at 32 . In the 1970 s, Con Edison and other property owners around Union Square in New York City began to sweep streets and sidewalks, while the local merchants' association attempted to garner financial support from other local businesses. The resulting donations were "sporadic and paltry," so Con Edison gave up the effort, "provoking an uproar from the same merchants who originally wouldn't pitch in." $I d$.

${ }^{18}$ See MacDonald, supra note 2, at 32 (noting that once a BID is formed, contributions from local merchants are mandatory, collected by the city under its normal taxing powers).

${ }^{19}$ See Briffault, supra note 8 , at 369 (explaining that BIDs ensure "that the revenues generated by the supplemental taxes imposed on district businesses and property owners are reserved for programs these taxpayers want, and are controlled by their representatives").

${ }^{20}$ See N.Y. GEN. MUN. LAWS $\$ 980-m$ (a) (McKinney 1999) (stating that "voting rep- 
burses the assessment to the BIDs. ${ }^{21}$ The BIDs use those funds to provide services that are supplemental to those provided by the city itself. $^{22}$ Each BID has a "district management association" operated by a board of directors that is entrusted with making strategic decisions concerning the provision of daily services. ${ }^{23}$

In New York, the state legislature passed its BID law in response to deteriorating conditions in business districts throughout many municipalities in the state. ${ }^{24}$ Like the special purpose districts noted above, the predecessors to New York BIDs were established in the 1970s, when cities "created special districts which collected assessments from property owners to pay for pedestrian malls and street improvements. ${ }^{25}$

\section{B. Forming a BID}

Several layers of approval are required before a BID is created. ${ }^{26}$ In New York City, for example, BID advocates must inform property owners and commercial tenants of the proposed BID, including its budget and tax assessment scheme, the services to be provided, and its territorial boundaries. ${ }^{27}$ Although no formal vote is required of property owners, BID proponents must continue to solicit support "until enough support has been generated and there seems to be general consensus on the boundaries, services, and budget of the proposed

resentation of owners of property and tenants within the district" may be "weighted in proportion to the assessment levied or to be levied against the properties within the district").

${ }^{21}$ See NeW YORK CTTY COUNCII FIN. COMM., CTIIES WITHIN CTIIES: BusINESS IMPROVEMENT DISTRICTS AND THE EMERGENCE OF THE MICROPOLIS 12 (1995) [hereinafter CIIIES WIIHIN CIIIES] (noting that "BID assessment bills are mailed annually by [the Department of Finance] to property owners").

${ }_{22}^{2}$ See Briffault, supra note 8, at 368 ("BIDs' services are provided in addition to those offered by city governments.").

${ }^{23}$ N.Y. GEN. MUN. LAWS $\$ 980$-m (requiring that a district management association exist to carry out the activities prescribed in a district plan).

${ }^{24}$ See Business Improvement District Act, 1989 N.Y. LAws ch. 282, $\$ 2$ (listing among the legislative findings the fact that "the business districts within many municipalities in the state are in a deteriorated condition"); see also Kessler v. Grand Cent. Dist. Management Ass'n, 960 F. Supp. 760, 763 (S.D.N.Y. 1997), affd, 158 F.3d 92 (2d Cir. 1998) (citing the legislative intent behind New York's BID legislation).

${ }^{25}$ CITIES WITHIN CITIES, supra note 21, at 5.

${ }^{26}$ The cumbersome approval process adds credibility to BID proponents' claim that the duly-elected city government exercises control over BIDs from inception to operation. For a discussion of BID autonomy, see infra Part II.A.

${ }^{27}$ See CITIES WITHIN CIIIES, supra note 21, at 8 (describing the requirements of BID formation). 
BID." ${ }^{28}$ Supporters then must compile a detailed district plan ${ }^{29}$ and forward it first to the Department of Business Services ("DBS"), which is the City agency that oversees all BIDs, and then to the City Council and other elected officials. ${ }^{30}$ Following an open public meeting, the City Planning Commission reviews the proposal and prepares a report approving or disapproving the district plan. ${ }^{31}$ The Commission then submits its report to the Mayor, Borough President, City Council, relevant council member or members, and the City Clerk. ${ }^{32}$

The City Council holds another public hearing and will receive objections to the plan for a period of thirty days. ${ }^{33}$ This process applies only to property owners-lessees in the district subject to commercial or residential leases do not have the right to file formal objections to the plan. Yet, if owners of at least fifty-one percent of the assessed valuation of benefited real property within the BID, or fiftyone percent of the owners of such property, file objections, the BID will not be established. ${ }^{34}$ Unless sufficient objections block a BID's creation, the City Council may vote to create the BID and to allow DBS to contract with the BID for the proposed supplemental services. $^{35}$ The Department of Finance ("DOF") collects annual assessments from property owners and provides the money to DBS, which distributes bi-weekly disbursement checks to the BID. ${ }^{36}$

At a time when "urban governments to a large extent dictate the quality of life in urban America," BID have been enormously successful in achieving real improvements.

${ }^{23}$ Id. (quoting NEW YORK CITY DEP'T OF BUS. SERVS., ESTABLISHING AND OPERATING A BUSINESS IMPROVEMENT DISTRICT: A STEP-BY-STEP GUIDE 4 (1984)).

${ }^{29}$ See N.Y. GEN. MUN. LAW $\$ 980$-a (McKinney 1999) (setting forth the required contents of the district plan).

${ }^{30}$ See CITIES WITHIN CITIES, supra note 21, at 9-10 (describing the various city agencies that must review the plan).

${ }^{31}$ See id. at 10 (describing the district plan registration process).

${ }^{32}$ See id. at 10-11 (explaining the approval process).

3s See id. (noting property owners' ability to object to the plan).

${ }^{34}$ See id. at 11 (describing the process whereby property owners may defeat a BID).

${ }^{35}$ See id. (listing the factors the City Council will consider before approving a BID).

${ }^{36}$ See id. at 12 (describing the process by which assessments are collected and distributed).

${ }^{37}$ Robert P. Inman \& Daniel L. Rubinfeld, The Judicial Pursuit of Local Füscal Equity, 92 HARV. L. REV. 1662, 1662-63 (1979) (describing the immense impact of local fiscal decisions on Americans' lifestyles).

${ }^{33}$ See Briffault, supra note 8, at 370 ("BIDs are credited with playing an important role in restoring urban morale and making older downtowns more attractive places to shop, visit, do business, and seek entertainment."). 
Nearly forty BIDs are in operation in New York City, ${ }^{39}$ and more than half of the states have statutes allowing localities to create similar improvement districts. ${ }^{40}$ Approximately one thousand BIDs already are in existence in the United States, and New York City's mayor, Rudolph Giuliani, has said that BIDs are "filling in for government." This phenomenon is perhaps most evident within the geographic area of the Grand Central Partnership.

\section{THE GRAND GENTRAL PARTNERSHIP}

\section{A. The Grand Central Partnership Defined}

The Grand Central BID covers seventy-five blocks in midtown Manhattan's central business area, with Grand Central Terminal standing at its center. ${ }^{43}$ It encompasses a high-rent commercial area with several architectural landmarks, including the Chrysler Building, the Daily News Building, and St. Bartholomew's Church. ${ }^{44}$ It contains

${ }^{39}$ See CrIIES WITHIN CrTTES, supra note 21, at 7-8 (listing the BIDs in operation and those pending approval in 1995); David Seifman, Hizzoner Lashes Out at City's Big BIDNess, N.Y. Post, May 3, 1998, at 20 (reporting that New York City has 39 BIDs). There is a wide discrepancy in the tax base for these BIDs, however. While the Grand Central Partnership has a $\$ 10$ million annual budget, the White Plains Road BID in the Bronx has a budget of $\$ 65,000$, and the Church Avenue BID in Brooklyn has a budget of $\$ 110,000$. See Doug Lasdon \& Sue Halpern, When Neighborhoods Are Privatized, N.Y. TIMES, Nov. 30, 1995, at A29 (demonstrating the great variation in BID budgets).

${ }^{40}$ Variations in the methods by which states authorize BIDs or BID-like organizations make obtaining an exact count difficult. One commentator identified 27 states that authorize such organizations. See Mark S. Davies, Business Improvement Districts, 52 WASH. U. J. URB. \& CONTEMP. L. 187, $187 \mathrm{n.2}$ (1997) (listing the states and their authorizing statutes). Another identifies 40. See David J. Kennedy, Note, Restraining the Power of Business Improvement Districts: The Case of the Grand Central Partnership, 15 YAIE L. \& POL'Y REV. 283, 290-91 n.61 (1996) (same); see also Briffault, supra note 8, at 368 n.7 (agreeing with Kennedy's count).

${ }^{11}$ See Lawrence O. Houstoun, Jr., Business Improvement Districts, ECON. DEv. COMMENTARY, Spring 1996, at 4, 5 (explaining that there are between one and two thousand BIDs in the United States and Canada). Some commentators have even argued for block-level improvement districts, with broader powers than existing BIDs. See, e.g., Robert C. Ellickson, New Institutions for Old Neighborhoods, 48 DUKE L.J. 75, 97100 (1998) (suggesting a broad range of supplementary services this type of district might provide). Similar proposals have been offered for purely residential neighborhoods in New York City, such as the Upper East Side. See Lueck, supra note 5 (reporting on the battles surrounding the proposed creation of an Upper East Side security force).

${ }^{42}$ Lueck, supra note 4, at 1 .

${ }^{13}$ See KELIJNG \& COLES, supra note I, at 113 (describing the geographic area of the Grand Central Partnership).

"See id. 
more than fifty-one million square feet of commercial real estate, accounting for fourteen percent of Manhattan's total office space. ${ }^{45}$ The property within the GCP was valued at approximately $\$ 7.8$ billion in 1994. The BID's security patrol has produced a sixty percent drop in crime, taxi dispatchers maintain orderly queues outside Grand Central Station, and new lampposts, planters, and trash receptacles sit on nearly every block in the district ${ }^{47}$ Dan Pisark, a director of the Grand Central Partnership, noted that "new stores have opened, and existing ones are investing in expansions, with vacancies as low as $2 \% . "{ }^{n 8} \mathrm{Nei}-$ ther proponents nor critics can deny the positive impact of the GCP.

\section{B. Function of the Grand Central Partnership}

In its district plan, the GCP sought to contract with DBS to offer the following supplemental services: security, sanitation, tourist information, social services for homeless persons, special maintenance and repair, public events, and retail improvements. ${ }^{49}$ Today, the GCP has a security force of sixty-three officers, who are in close radio communication with the New York City Police Department. ${ }^{50}$ Members of the GCP security staff are "either licensed security guards or peace officers. ${ }^{, 51}$ While most are unarmed, some licensed supervisors do carry weapons. ${ }^{52}$ The GCP also has a thirty-eight person sanitation force to "clean streets and sidewalks, wash street signs, paint fire hydrants, and remove graffiti in the District. ${ }^{, 53}$ It operates a tourist information

${ }^{45}$ See MacDonald, supra note 2, at 33 (describing the GCP BID).

${ }^{46}$ See id.

${ }^{47}$ See id. at 29 (noting the significant change in the Grand Central area).

${ }^{48}$ Lorna Pappas, Baiting the Hook, NAT'I REAL ESTATE INVESTOR, Sept. 30, 1999, at 58,60 .

${ }^{49}$ See District PLAN AS AMENDED fOR thE GRAND CENTRAL BusinesS IMPROVEMENT DISTRICT IN THE CITY OF NEW YORK BOROUGH OF MANHATTAN 9-12 (1994) [hereinafter DISTRICT PLAN] (describing proposed services to be provided by the GCP). See generally Kessler v. Grand Cent. Dist. Management Ass'n, 960 F. Supp. 760, 764 (S.D.N.Y. 1997), affd, 158 F.3d 92 (2d Cir. 1998) ("The services provided by [Grand Central District Management Association] are not meant to substitute for those provided by the City, but rather are supplemental to those the City provides." (citation omitted)).

${ }^{50}$ See Kessler, 960 F. Supp. at 764 (describing the GCP security provisions). See also Kessler v. Grand Cent. Dist. Management Ass'n, 158 F.3d at 113 (Weinstein, J., dissenting) (explaining that some officers may make warrantless arrests and searches by virtue of their peace officer status).

${ }^{51}$ Kessler, 960 F. Supp. at 764.

${ }^{52}$ See id. (noting that "[a]ll members of the GCP security staff are unarmed, except for licensed supervisors").

${ }^{53}$ Id. 
booth in Grand Central Terminal and five tourist carts located throughout the district. ${ }^{54}$ The GCP also runs an outreach, assessment, and referral facility for the homeless that includes food service and job training. ${ }^{55}$ It undertakes horticultural maintenance, plans public events, and helps retailers improve their visual impact on the district. ${ }^{56}$

Despite the apparent breadth of the GCP's municipal powers, it does not provide all of the services of a general city government elected under a traditional voting structure. ${ }^{57}$ The GCP, for example, "does.not operate any school systems, court systems, or administrative tribunals, nor does it prosecute crimes, maintain jails, provide fire services, license motor vehicles, license vendors, operate public libraries, record deeds, have enforcement authority over consumer protection, environmental protection, traffic laws, or animal control. ${ }^{, 58}$

The GCP district is dominated by commercial entities, yet nearly one thousand individuals own or lease residential property within its boundaries. To such residents, the GCP serves an important role in determining the provision of public services that affect them. It is for these individuals that the GCP's voting structure presents the most serious constitutional problems. The Kessler plaintiffs alleged that where a local government provides general services that affect all citizens, any limitation on the franchise is highly suspect. ${ }^{59}$ The defendants in that case responded that the GCP was limited in purpose, and that traditional guarantees of voter equity should not apply in such special districts. $^{60}$ To set the stage for the Kessler action, the following section explores the development of the one person, one vote principle and its application to local governmental entities.

${ }^{54}$ See id. at 765 (describing "tourist information services" operated by the GCP).

${ }^{55}$ See id. (describing various social services provided for the homeless in the district). The outreach program became a lightning rod for criticism in 1995 when the GCP allegedly instructed outreach workers to beat homeless people to encourage them to leave the district. See infra text accompanying notes 190-92 (describing allegations that the GCP employed outreach workers as "goon squads" to beat the homeless and the repercussions of those allegations).

${ }_{56}$ See DistrICT PLAN, supra note 49 , at $9-12$ (providing a detailed description of services provided by the GCP).

${ }^{57}$ See Kessler, 960 F. Supp. at $764 \mathrm{n} .2$ (describing traditional functions of city governments which the GCP does not perform).

${ }^{5 s} I d$.

${ }^{59}$ See id. at 770 (explaining that "as tenants, they are not represented on the Board in proportion to their number," thus violating the principle of one person, one vote).

${ }^{60}$ See id. at 766. 


\section{LIMITATIONS ON FRANCHISE}

\section{A. The Establishment of the One Person, One Vote Principle}

The Supreme Court set forth the principle of "one person, one vote" as a necessary condition of political equality in Reynolds $v$. Sims. ${ }^{61}$ At issue in Reynolds was an Alabama legislative apportionment scheme that divided districts without regard to population. ${ }^{62}$ The result was that the vote of citizens residing in more highly populated districts was worth less in relation to those in the less populated districts. ${ }^{63}$ Rejecting the State's historical, economic, and other group factor justifications, the Court concluded that every qualified resident had the right to a ballot of equal weight for the election of state legislators. ${ }^{64}$ Chief Justice Warren, writing for the majority, asserted an "inalienable right to full and effective participation in the political processes. ${ }^{, 65} \mathrm{He} \mathrm{rec-}$ ognized that because the opportunity to exercise the franchise in a free and unimpaired manner is necessary to preserve other basic civil and political rights, any alleged infringement on the right to vote

${ }^{61} 377$ U.S. 533, 565-67 (1964).

${ }^{62} I d$. at 540 (challenging the apportionment scheme because it subjected some voters to "serious discrimination with respect to the allocation of legislative representation").

${ }^{63}$ See id. at 562 (explaining that if citizens in one part of the state were given two, five, or ten times the weight of votes of citizens in another part of the state, the latter citizens' votes would be effectively diluted).

${ }^{64}$ See id. at 567 ("The fact that an individual lives here or there is not a legitimate reason for overweighting or diluting the efficacy of his vote.").

${ }^{65}$ Id. at 565; see also United States v. Carolene Prods., 304 U.S. 144, 152-53 n.4 (1938) (recognizing the importance of safeguarding participation in the electoral process by noting that "prejudice ... tends seriously to curtail the operation of those political processes ordinarily to be relied upon to protect minorities, and ... call[s] for a correspondingly more searching judicial inquiry"); Yick Wo v. Hopkins, 118 U.S. 356, 370 (1886) (referring to the political franchise of voting as a "fundamental political right, because [it is] preservative of all rights"). Prior to Reynolds, the Supreme Court already had concluded that the constitutionality of a state's apportionment of its legislative seats presented a justiciable controversy subject to adjudication by federal courts. See Wesberry v. Sanders, 376 U.S. 1, 4 (1964) (holding that attacks on the constitutionality of congressional districting plans are justiciable); Baker v. Carr, 369 U.S. 186, 237 (1962) (recognizing a cause of action in the claim that votes in overpopulated state legislative districts were underweighted, while votes in underpopulated districts were overweighted). The Court also had already concluded that the Constitution prohibited a state from using a county unit system for counting votes for statewide offices, and thus diluting votes without regard for population. See Gray v. Sanders, 372 U.S. 368, 379 (1963) (" $[\mathrm{A}] 11$ who participate in the election are to have an equal vote-whatever their race, whatever their sex, whatever their occupation, whatever their income, and wherever their home may be in that geographical unit."). 
must be subjected to careful and meticulous scrutiny. ${ }^{66}$

The Reynolds Court reserved judgment on whether the one person, one vote principle would be applicable to political subdivisions of states, such as counties or cities. In dicta, Justice Warren noted that local governments are "subordinate governmental instrumentalities created by the State to assist in the carrying out of state governmental functions. ${ }^{367}$ At the time, those who opposed extending the one person, one vote principle to cities and counties argued that because the number and nature of their powers rested in the state's absolute discretion, they were not constrained by the same equal protection requirements as the state itself. ${ }^{68}$ Yet, as states delegated more and more powers to local entities, the Court became duly skeptical. This skepticism culminated in the extension of the one person, one vote principle to local governments in $1968 .^{69}$

\section{B. Extension of One Person, One Vote to Local Governments}

The Court applied the Reynolds one person, one vote principle to local governments in Avery v. Midland County. ${ }^{70}$ Avery was a taxpayer and voter in Midland County, Texas, who alleged that the selection of the local Commissioners Court from single-member districts of substantially unequal populations violated his right to Equal Protection under the Fourteenth Amendment. ${ }^{71}$ Because the Commissioners Court exercised "general governmental powers over the entire geo-

${ }^{66}$ See Reynolds, 377 U.S. at 562 (noting that the Court had previously referred to the franchise of voting as a fundamental right (citing Yick Wo, 118 U.S. at 370)); see also Burdick v. Takushi, 504 U.S. 428, 434 (1992) ("[W] hen [voting rights] are subjected to 'severe' restrictions, the regulation must be 'narrowly drawn to advance a state interest of compelling importance." (quoting Norman v. Reed, 502 U.S. 279, 289 (1992))).

${ }^{67}$ Reynolds, 377 U.S. at 575.

${ }^{6}$ See id. (finding that cities and counties are subordinate governmental instrumentalities created by the state to assist in carrying out state government functions, not sovereign entities, and their powers rest in the absolute discretion of the state); see also Hunter v. City of Pittsburgh, 207 U.S. 161, 178 (1907) (holding that localities are administrative arms of the state, not separate, autonomous governments).

${ }^{69}$ See Avery v. Midland County, 390 U.S. 474, 484-85 (1968) (holding that "the Constitution permits no substantial variation from equal population in drawing districts for units of local government").

${ }^{70} I d$.

${ }^{71}$ See id. at 475-76 (outlining Avery's complaint and explaining that the "vast imbalance ${ }^{n}$ in district populations resulted from placing virtually the entire city of Midland, the county's only urban center, in a single district). 
graphic area served by the body," to a vote of equal weight to all other voters electing its members. The respondents countered that because the functions performed by the Commissioners Court were not legislative, but administrative, the body was nothing more than an arm of the state of Texas. ${ }^{73}$ The respondents also contended that because the governmental body's activities disproportionately affected rural dwellers, the principle of one person, one vote should not apply. ${ }^{74}$

In finding for Avery, the Supreme Court considered the significant policy and decision-making authority left to local governments in the form of local home rule, ${ }^{75}$ immune from state legislative interference. The Court concluded that there was little difference between the "exercise of state power through legislatures and its exercise by elected officials in cities, towns, and counties." ${ }^{\prime 6}$ The majority held that "when the State delegates lawmaking power to local government and provides for the election of local officials from districts specified by statute, ordinance, or local charter, it must insure that those qualified to vote have the right to an equally effective voice in the election process." "77 The Court went on to explain that while the Commissioners Court made more decisions affecting rural dwellers, it had the power to affect all citizens-rural and urban. ${ }^{78}$

Like the Reynolds Court before it, the Avery Court stopped short of requiring that the one person, one vote principle be applied to all

${ }^{72}$ Id. at 485. The Court stated that:

"[The Commissioners Court] is the general governing body of the county. It establishes a courthouse and jail, appoints numerous minor officials such as the county health officer, fills vacancies in the county offices, lets contracts in the name of the county, builds roads and bridges, administers the county's public welfare services, performs numerous duties in regard to elections, sets the county tax rate, issues bonds, adopts the county budget, and serves as a board of equalization for tax assessments."

Id. at 476 (quoting VERNON'S ANN. TEX. CONST. art 5, § 18 interpretive commentary (1955)).

${ }^{73}$ See Avery, 390 U.S. at 482.

${ }^{74}$ See id. at 484 (recognizing the County's argument that the Commissioners Court concentrated its attention on rural roads).

${ }^{75}$ "Home rule" is defined as a state constitutional provision or type of legislative action that results in apportioning power between state and local governments by providing local cities and towns with a measure of self-government. See BLACK'S LAW DICTIONARY 733 (6th ed. 1990).

${ }^{76}$ Avery, 390 U.S. at 481.

7 Id. at 480.

${ }^{78}$ See id. at 484 (" [T] he relevant fact is that the powers of the Commissioners Court include the authority to make a substantial number of decisions that affect all citizens, whether they reside inside or outside the city limits of Midland. ${ }^{n}$ ) 
governmental elections. The Avery Court left open the question of whether a "special-purpose unit of government assigned the performance of functions affecting definable groups of constituents more than other constituents" might be immune from the one person, one vote requirement. ${ }^{79}$ In two forceful dissents, Justices Harlan and Fortas emphasized the importance of allowing state legislatures to create specialized governmental schemes that give weight to the votes of those whom the government affects most. ${ }^{80}$ Justice Harlan argued that where the function of a government disproportionately affects a subgroup, such as the rural dwellers in Avery, then extending the vote to city residents actually denies the subgroup a proportional voice, undermining the "constitutional experiment" of Reynolds. ${ }^{81}$ Justice Fortas criticized the majority's stringent application of one person, one vote as "completely ignor[ing] the complexities of local government... which Reynolds itself states, demand latitude of prescription." ${ }^{82}$

\section{Striking Down Local Vote Restrictions}

Continuing to federalize local election law, ${ }^{83}$ the Supreme Court struck down a host of restrictive local voting schemes following Avery. In Kramer v. Union Free School District No. 15, the Court considered the constitutionality of a New York statute that limited the right to vote in local school board elections to owners or renters of taxable property within the school district and to parents of enrolled children. ${ }^{84}$ The school board in question did not have general governmental func-

${ }^{79} I d$. at $483-84$.

${ }^{80}$ See id. at 492 (Harlan, J., dissenting) (arguing that the majority's decision "deprives localities of the desirable option" of varying the size of the constituencies of specialized units of government "so as rationally to favor those whom the government affects most"); id. at 500 (Fortas, J., dissenting) (noting that the functions of many specialized local bodies of government "have only slight impact on some of their constituents and a vast and direct impact on others").

${ }^{81}$ Id. at 491-94 (Harlan, J., dissenting) (noting that under the majority's standard "little or no allowance may be made for the greater stake of the rural inhabitants in the county government").

${ }^{82}$ Id. at 499 (Fortas, J., dissenting).

${ }^{83}$ See Richard Briffault, Who Rules at Home?: One Person/One Vote and Local Governments, 60 U. CHI. L. REV. 339, 340 (1993) (arguing that although there has been significant federalization of local election law, such federalization "has been partial, [with the states retaining] considerable control over the organization and structure of local governments").

${ }^{84} 395$ U.S. 621, 622 (1969) (describing the content of section 2012 of the New York Education Law). 
tions-its only responsibilities were school operation, prescription of courses of study, and determination of the textbooks to be used. ${ }^{85}$ Those permitted to vote under the existing scheme not only elected the board but also approved the school's annual budget. ${ }^{86}$ The plaintiff, who had no children and lived in an apartment with his parents, sought to participate in the elections. ${ }^{87}$

The State justified the voting scheme by arguing that educational policy was best left to those with "direct and definable" interests in the policy-that is, parents of school children and the owners or lessees of taxable property who were burdened with the cost of funding the schools. ${ }^{88}$ Kramer argued that he was denied equal protection because he was foreclosed from participating in important policy decisions-decisions which "he and others of his class are substantially interested in and significantly affected by."

The Kramer Court held that while the State was not required to provide an elective school board, having done so, the legislature's definition of the electorate was subject to strict scrutiny. ${ }^{90}$ The mere existence of an election concerned the Court more than any specific power or authority possessed by the school board. ${ }^{91}$ Striking down the voting scheme, the Court explained that there was no compelling interest in limiting the franchise in a manner that included those with "a remote and indirect interest in school affairs" such as a renter of taxable property with no children, while "exclud[ing] others who have a distinct and direct interest in the school meeting decisions. ${ }^{, 92}$

${ }^{85}$ See id. at 623-24.

${ }^{85}$ See id. at 624 (noting that the local voters "must approve the school budget submitted by the school board").

${ }^{87}$ See id. at 625.

ss See id. at 630-31.

${ }^{89} I d$. at 630.

${ }^{90} \mathrm{See}$ id. at 629 (noting that "once the franchise is granted to the electorate, lines may not be drawn which are inconsistent with the Equal Protection Clause of the Fourteenth Amendment" (quoting Harper v. Virginia Bd. of Elections, 383 U.S. 663, 665 (1966))).

${ }^{92}$ See id. ("Our exacting examination is not necessitated by the subject of the election; rather, it is required because some resident citizens are permitted to participate and some are not.").

${ }^{92}$ Id. at 632 . The Court recognized that the statute also "disenfranchised senior citizens and others living with children or relatives; clergy, military personnel, and others who live on tax-exempt property; boarders and lodgers; parents who neither own nor lease qualifying property and whose children are too young to attend school and whose children attend private schools." Id. at 630 . Kramer did not challenge restrictions on residence, age, or citizenship also present in the statute. See id. at 625 (noting that the parties agreed that "the States have the power to impose reasonable citizen- 
That same year, in City of Phoenix v. Kolodziejski, the Court granted certiorari to determine whether a state may restrict the franchise so that only real property taxpayers may vote in elections to approve the issuance of general obligation bonds. ${ }^{93}$ These bonds were to be issued to finance "municipal improvements," such as "parks and playgrounds, police and public safety buildings, and libraries." ${ }^{.94}$ Property taxes were to be levied to service the indebtedness, burdening the property owners directly. ${ }^{95}$ The State justified this scheme by arguing that decisions on bonds should be left to property owners because of their pecuniary interest in supporting the bond issue. ${ }^{96}$

The Kolodziejski Court looked to the municipal improvements that would be financed by the bond issuance and found that the benefits would accrue to property owners and non-owners alike. ${ }^{97}$ Because all residents would be substantially affected by the outcome of the election, the Court held that the Constitution would not permit the exclusion of qualified, non-property-owning electors from the franchise. ${ }^{98}$ The Court also noted that property owners would likely pass on the burden to tenants "in the form of higher rent," and commercial property owners would pass on the burden to the Phoenix residents in the form of higher "prices for goods and services."

Reaching a high water mark in striking down voting restrictions, the Court invalidated a plan that granted a disproportionate vote to electors of trustees for a junior college district in Hadley $v$. Junior College District. ${ }^{100}$ This district had far fewer governmental powers than those possessed by the Avery Commissioners Court. ${ }^{101}$ This voting

ship, age, and residency requirements on the availability of the ballot").

93399 U.S. 204, 205 (1969); cf. Cipriano v. City of Houma, 395 U.S. 701, 702 (1969) (per curiam) (holding that a Louisiana law that gave the right to vote in elections to approve the issuance of revenue bonds for a public utility only to property taxpayers violated the Equal Protection Clause).

${ }^{94}$ Kolodziejski, 399 U.S. at 206.

${ }^{95}$ See id. at 205-08.

${ }^{95}$ See id. at 208 (noting the State's argument that the law is justified because it recognized "the unique interests of real property owners").

${ }_{97}$ See id. at 209 (explaining that all residents of Phoenix "have a substantial interest in the public facilities and the services available in the city and will be substantially affected by the ultimate outcome of the bond election").

See id.; see also infra Part IV.C.I (discussing the provision of public goods).

${ }^{99}$ Kolodziejski, 399 U.S. at 211.

${ }^{100} 397$ U.S. 50 (1970).

101 The Hadley trustees had the power to "levy and collect taxes, issue bonds with certain restrictions, hire and fire teachers, make contracts, collect fees, supervise and discipline students, pass on petitions to annex school districts, acquire property by condemnation, and in general manage the operations of the junior college." Id. at 53. 
scheme apportioned the junior college trustees on the basis of school enumeration, ${ }^{102}$ yet gave the voters of a constituent school district with sixty percent of the total school enumeration in the junior college district only fifty percent of the representation on the board. ${ }^{103}$ While the trustees' decisions primarily involved school functions, the Court concluded that the powers were "general enough" and had "sufficient impact throughout the district" to make the disproportionate voting scheme impermissible. ${ }^{104}$ Finding that the college trustees were governmental officials "in every relevant sense of that term," 105 the Court held that their election had to comply with Reynolds's and Avery's one person, one vote mandate. ${ }^{106}$

\section{The Special Limited Purpose Exception to the One Person, One Vote Principle}

The Court had often hinted that there could be an exception to the Reynolds rule if the body to be elected served a special limited purpose. ${ }^{107}$ That exception was invoked first in Salyer Land Co. v. Tulare Lake Basin Water Storage District ${ }^{108}$ and again in Ball v. James. ${ }^{109}$ In these cases, the Court held that when a government subdivision serves a "special limited purpose," and has a disproportionate impact on definable groups of constituents, it may be free from the equal protection constraints of the one person, one vote rule. ${ }^{110}$ In Salyer, plaintiff

The Court concluded that while these powers were not as broad as those of the Midland County Commissioners in Avery, they represented "important governmental functions." Id. at 53-54.

${ }^{102}$ School enumeration is defined as "the number of persons between the ages of six and 20 years [residing] in each district." Id. at 51 (citing MO. REv. STAT. $\$ 167.011$ (Supp. 1967)).

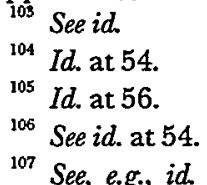

${ }^{107} \mathrm{See}$, e.g., id. at 56 ("It is of course possible that there might be some case in which a State elects certain functionaries whose duties are so far removed from normal governmental activities and so disproportionately affect different groups that a popular election in compliance with Reynolds might not be required ...."); Avery v. Midland County, 390 U.S. 474, 483-84 (1968) (explaining that a "special-purpose unit of government assigned the performance of functions affecting definable groups of constituents more than other constituents" might be exempted from the one person, one vote rule); Reynolds v. Sims, 377 U.S. 533, 575 (1964) (noting in dicta that the one person, one vote requirement did not apply to cities or other political subdivisions of states because they were merely "subordinate governmental instrumentalities").

${ }^{103} 410$ U.S. 719 (1973).

${ }^{109} 451$ U.S. 355 (1981).

${ }^{110}$ See Ball, 451 U.S. at 370 ("[T]he functions of the [local government entity at 
landowners, landowner-lessees, and residents of the defendant's district challenged the constitutionality of a California statute that limited the vote for the board of directors of the Tulare Lake Basin Water Storage District ("TLB") to landowners within the district. ${ }^{\text {"l }}$ The legislative purpose of the TLB was to facilitate a local response to water problems, including flood control and storage and distribution of water to farms within the district. ${ }^{112}$ The TLB served an exclusively agricultural area with seventy-seven residents. The Court explained the TLB's functions but distinguished them from general public services as follows:

[T]o provide for the acquisition, storage, and distribution of water for farming in the Tulare Lake Basin. It provides no other general public services such as schools, housing, transportation, utilities, roads, or anything else of the type ordinarily financed by a municipal body. There are no towns, shops, hospitals, or other facilities designed to improve the quality of life within the district boundaries, and it does not have a fire department, police, buses or trains.

In light of its narrow purpose, and pursuant to the exceptions recognized in Reynolds, the Court exempted the TLB's authorizing legislation from the strict scrutiny generally applied to franchise restrictions in favor of rational basis review. ${ }^{114}$ It then concluded that because restricting the vote to the disproportionately affected landowners was rationally related to a legitimate state interest, the law was constitutional. ${ }^{115}$ The Court viewed the TLB as a harmless administrative body, unlike the more liberally empowered government bodies at issue in Avery and its progeny. ${ }^{116}$

In 1981, the Court broadened the scope of the "special limited

issue] are therefore of the narrow, special sort which justifies a departure from the popular-election requirement of the Reynolds case."); Salyer, 410 U.S. at 728 (holding that a local government unit was entitled to the exception made in Reynolds "by reason of its special limited purpose and of the disproportionate effect of its activities on landowners as a group").

"II See Salyer, 410 U.S. at 723-25 (describing the functions and governance of the districts created under the California Water Code).

${ }^{112}$ See id. at 723 (listing the statutory powers granted to the TLB regarding waterrelated projects).

${ }^{113} I d$. at 728-29 (footnote and citations omitted).

${ }^{114}$ See id. at 728 (recognizing that the Reynolds exception applied to the TLB because of its limited authority).

${ }^{115}$ See The Supreme Court, 1980 Term, 95 HaRv. L. REv. 93, 184 (1981) (explaining the two-step test applied by the Court in Salyer).

${ }^{116}$ See Briffault, supra note 8, at 434-35 (analyzing how the Salyer water project fulfilled the requirements of the Avery exception). 
purpose" exception in Ball v. James. ${ }^{117}$ At issue was the Salt River Project Agricultural Improvement and Power District ("SRP"), which, unlike the TLB, affected metropolitan areas and included almost half of Arizona's population. ${ }^{118}$ The SRP was authorized to store and deliver water to owners of 236,000 acres of land in Arizona and to sell electricity to thousands of people to subsidize its water operations. It also had the power to assess property taxes, with the assessments serving as liens on the property, and it could condemn land under the power of eminent domain. ${ }^{119}$

Under the SRP scheme, the right to vote in directorial elections was limited to landowners, and votes were apportioned according to acreage owned. Plaintiffs were registered voters in the district who owned either no land or less than an acre of land. They alleged that because the SRP had the governmental authority to condemn land and to sell tax-exempt bonds, and because it sold electricity to virtually all district residents regardless of property ownership, election to its board should be governed by the one person, one vote principle. ${ }^{120}$

The Supreme Court held that the SRP had a narrow function that did not trigger the strict scrutiny of Reynolds, noting that " $[t]$ he District cannot impose ad valorem property taxes or sales taxes. It cannot enact any laws governing the conduct of citizens, nor does it administer such normal functions of government as the maintenance of streets, the operation of schools, or sanitation, health, or welfare services." ${ }^{121}$ The Court concluded that, like the private administration of water resources, ${ }^{122}$ the provision of electricity is not a traditional element of governmental sovereignty. ${ }^{123}$ Therefore, the electorate of such a special purpose unit of government "may be apportioned to give greater influence to the constituent groups found to be most af-

${ }^{117} 451$ U.S. 355, 361 (1981). For a discussion of the extent to which Ball v. James broke from the principles of Reynolds, see William H. Riker, Democracy and Representation: A Reconciliation of Ball v. James and Reynolds v. Sims, 1 SUP. CT. ECON. REv. 39, 39-41 (1982).

${ }^{118}$ See Ball, 451 U.S. at 365 (comparing the structures of the TLB and the SRP and concluding that the SRP was wider in scope).

119 See id. at 357.

${ }^{120}$ See id. at 360 (discussing the basis of plaintiffs' constitutional claims).

121 Id. at 366.

122 See Salyer, 410 U.S. at 723,729 (listing the water-related services provided by the TLB and finding that those activities did not constitute a traditional governmental function).

${ }^{123}$ See Ball, 451 U.S. at 368 (discussing why the provision of specific utilities should not trigger the Reynolds doctrine). 
fected by the governmental unit's functions."

\section{Summarizing Salyer and Ball}

For purposes of the Reynolds analysis, Salyer and Ball set forth two criteria for distinguishing proprietary enterprise from democratic local governments: (1) disproportionate impact on landowners, and (2) a special limited purpose. ${ }^{125}$ While this appears to be a simple test, in practice it has produced confusing results, forcing courts to engage in elaborate factual inquiries of impact and purpose. Some have found the Court's justification for the exception to be unpersuasive, charging that "the Court does not have a consistent theory for why local electoral systems should follow particular paradigms." 26 Professor Briffault has argued that the first criterion is "circular" and the second can be arbitrary. ${ }^{127}$ He has explained this argument by drawing a distinction between "proprietary" and "democratic" visions of construing impact. A "proprietary model" assesses impact by considering only those who bear the economic burden of the local government's action, while under the "democratic model," all persons benefited by the performance of services are considered to be affected. ${ }^{128}$

[W] hether a district's actions have a disproportionate impact on a landowner constituency will turn on whether disproportionate impact is viewed through a proprietary or a democratic lens; yet the presence or absence of a disproportionate impact on landowners is supposed to determine whether the proprietary or democratic framework is applied. The analysis is entirely circular.

....

Even for districts that provide just one or a handful of services and that have a landowner or taxpayer constituency, Ball and Salyer provide no theory for distinguishing general governmental functions from special limited purposes.

Because governmental activities "cannot easily be classified in ... neat categories," ${ }^{, 130}$ the application of Salyer and Ball has presented many problems. The Supreme Court has long recognized that the "science

124 Town of Lockport v. Citizens for Community Action at the Local Level, Inc., 430 U.S. 259, 266 (1977) (citing Salyer, 410 U.S. at 719).

${ }^{125}$ See Ball, 451 U.S. at 364 (utilizing the two-pronged Salyeranalysis).

${ }^{126}$ Robert C. Ellickson, Cities and Homeowners Associations, 130 U. PA. L. REV. 1519, 1543 (1982).

${ }^{127}$ Briffault, supra note 83, at 370.

${ }^{123}$ See id. at 370-71 (explaining the proprietary and democratic models).

${ }^{129}$ Id. at 371, 373.

1so Avery v. Midland County, 390 U.S. 474, 482 (1968). 
of government ... has but few fixed principles, and practically consists in little more than the exercise of a sound discretion, applied to the exigencies of the state as they arise. ${ }^{\text {"131 }}$ With few fixed principles, government is often forced to experiment-as it did in creating special districts-to address such exigencies. While special districts likely will continue to play a role in local governance, the Salyer and Ball precedents have created a confusing doctrine that is reflected in the inconsistent way lower courts have evaluated these cases.

\section{Treatment of the Salyer Exception by Lower Courts}

The lack of guidance by the Supreme Court in evaluating special districts has forced lower courts to engage in a fact-specific inquiry into whether "governmental" powers exist and whether they have a disproportionate impact on the group afforded the voting right. Prior to Kessler, three circuit court cases were handed down that illustrate how courts afford varying weight to considerations of purpose and impact.

In one such case, the Second Circuit held that a voting scheme to elect a school board with the power to propose budgets and to borrow, but not to tax, did not fall under the "special limited purpose" exception to the Reynolds rule. ${ }^{132}$ At issue in Baker $v$. Regional High School District No. 5 was a scheme for electing school board members in Connecticut from towns of substantially differing populations. ${ }^{133}$ The school district had the power to initiate and to propose expenditures for the district, but it did not have the broad taxation power of the junior college district in Hadley. ${ }^{134}$ Like the Hadley Court, the Second Circuit concluded that the district carried out governmental functions and that the one person, one vote principle should apply. ${ }^{135}$ Distinguishing this case from the "limited purpose" districts in Salyer, the court noted that the school district's general power impacted all vot-

\footnotetext{
${ }^{131}$ Anderson v. Dunn, 19 U.S. (6 Wheat.) 204, 226 (1821).

${ }^{132}$ See Baker v. Regional High Sch. Dist. No. 5, 520 F.2d 799, 802-03 (2d Cir.), cert. denied, 423 U.S. 995 (1975).

${ }^{133}$ See id. at 800 (noting that while there was a large disparity in town sizes, as well as in the number of students from each town and in each town's fiscal contribution to the district, the three towns had equal representation).

${ }^{134}$ See id. at 801.

${ }^{135}$ See id. at 801-02 (holding that the regulatory and supervisory powers were sufficiently broad to constitute governmental activity).
} 
ers. $^{136}$

Similarly, the Tenth Circuit struck down a restrictive voting scheme that applied to a state agency that had regulatory power, but no power to tax, spend, or propose budgets. ${ }^{137}$ In Hellebust v. Brownback, the court held that the one person, one vote rule would apply to elections for a state's board of agriculture principally because of the "breadth of oversight exercised" by the board. ${ }^{138}$ In that case, the board, which was elected by delegates from various agricultural organizations, had regulatory powers that affected all Kansas residents. These powers included inspecting milk and meat, regulating pesticides, and removing water from rivers and aquifers throughout the state. ${ }^{139}$ Because the board functions "materially affect[ed] residents of Kansas who [were] not represented," the Tenth Circuit struck down the voting scheme as a violation of equal protection. ${ }^{140}$

In contrast, the Seventh Circuit upheld a restrictive voting scheme for a school board, emphasizing the board's inability to levy taxes. ${ }^{141}$ In Pittman v. Chicago Board of Education, Chicago public school principals challenged state laws that created local school councils and limited the eight representatives on such councils to six parents and two residents of the district. ${ }^{142}$ The principals themselves sought to be considered as candidates. Despite obvious similarities to the junior college district in Hadley, the court upheld the district, relying on the important factual distinction that the Chicago school districts lacked the power to tax. ${ }^{143}$

\section{THE KESSLER CHALLENGE}

The controversy surrounding BIDs and the confusing doctrine created by Salyer and Ball suggest that the Supreme Court soon might

${ }^{136}$ See id. at 802 (explaining that while the water districts' actions disproportionately affected the landowners in Salyer, the schools district's powers affected everyone in this instance, and also noting that Salyer specifically mentioned schools as a general public service).

137 See Hellebust v. Brownback, 42 F.3d 1331, 1332 (10th Cir. 1994).

139 Id.

139 See id. at 1333 (listing the powers of the board).

140 Id. at 1334.

141 See Pittman v. Chicago Bd. of Educ., 64 F.3d 1098, 1100, 1105 (7th Cir. 1995), cert. denied, 517 U.S. 1243 (1996).

142 See id. at 1100.

14 See id. at 1102 (explaining that while the power to tax is not dispositive, it is contextually important in light of the fact that the council was not the overall governing board). 
be called upon to address whether "business improvement" is a special limited purpose as contemplated by its precedents. The Second Circuit recently upheld a restrictive voting scheme in Kessler v. Grand Central District Management Ass'n, a case that involved a challenge to a law guaranteeing majority representation on the governing board to property owners within the BID. ${ }^{144}$ The disputed scheme divided board representatives into four classes-A, B, C, and D. ${ }^{145}$ The GCP Bylaws provided that Class A Directors, elected by Class A members (owners of real property), would constitute a majority of the Board at all times. ${ }^{146}$ Within Class $A$, property owners had their votes weighted in proportion to the assessed valuation of their land, and the number of Class B and C Directors was to be established by the Board "from time to time." ${ }^{\text {147 }}$ Class $D$ directors were four individuals, each appointed by a specific City official. ${ }^{148}$

At the time of the trial, there was only one Class $\mathrm{G}$ representative serving on the board to represent the 930 people who lived in co-ops or rental apartments within the district. In contrast, the area's 242 property owners had thirty-one representatives. ${ }^{149}$ Plaintiffs were tenant-shareholders of 372 Fifth Avenue Owners, Inc., a cooperative apartment building on 35th Street that fell within the territory of the GCP. ${ }^{150}$ Because the cooperative held fee title to the building where the plaintiffs' apartments were located, the tenant-shareholders did not qualify as "owners of record of real property" as required for Class A membership. They were, instead, limited to Class C membership, reserved for occupants pursuant to leases of dwelling units. ${ }^{151}$ Class $\mathrm{C}$

144 158 F.3d 92 (2d Cir. 1998).

${ }^{145}$ The classes were divided as follows: Class A: Owners of real property in the BID's district; Class B: Tenants who are occupants pursuant to leases of commercial spaces; Class C: Occupants pursuant to leases of dwelling units; Class D: Persons serving as directors by virtue of their appointment by the Mayor, City Comptroller, Manhattan Borough President, and Majority Leader of the City Council. Each member class elected the director class of the same designation. See BYLAWS OF GRAND CENTRAL DISTRICT MANAGEMENT ASSOCTATION, INC. art. I, $\S 1$ [hereinafter BYLAWS] (identifying the classification of all corporation members). In the district court proceeding, the court found that Class A voters had 31 representatives on the Board, Class B had 16, Class $\mathrm{C}$ had one, and Class D had four. See Kessler v. Grand Cent. Dist. Management Ass'n, 960 F. Supp. 760, 766 (S.D.N.Y. 1997), affd, 158 F.3d 92 (2d Cir. 1998).

${ }^{146}$ See BYLAwS, supra note 145, art. II, $\S 1$.

${ }^{147} I d$. art. I, $\S 1$ (establishing the parameters for each director class).

${ }^{148}$ See id. (noting who may appoint Class D directors for service).

${ }^{149}$ See Kessler, 960 F. Supp. at 766.

${ }^{150}$ See id. at 763 (introducing the plaintiff class and the nature of its relationship to the GCP).

151 See BYLAWS, supra note 145, art. I, § I. 
directors were unable to constitute a majority of the board under New York law and the GCP Bylaws. ${ }^{152}$ The plaintiffs charged that the voting system "privilege[d] one class of district members over another without regard to actual number or place of residence," and that these limitations on their right to vote for a general-purpose governmental body should be subject to the one person, one vote principle and equal protection analyses. ${ }^{153}$ The GCP maintained that: "(a) it does not exercise general governmental powers, (b) it does not supplant or replace local government, (c) its activities are subject to the supervision and control of the city, and (d) its activities affect property owners disproportionately." 154

Relying on the exceptions carved out by Salyer and Ball, both the district court and the Second Circuit found the restrictive voting scheme to be permissible because the activities of the GCP disproportionately affected the property owners and served the limited purpose of promoting business in the area. ${ }^{155}$ According to the district court, the one person, one vote rule is applied only when a governmental body exercises "'general governmental powers' and 'perform[s] important governmental functions,' that ha[ve] significant effect on all citizens residing in the district." 156

Comparing the powers of the junior college trustees in Hadley ${ }^{157}$ and the water storage and agricultural improvement districts in Salyer ${ }^{153}$ and Ball $^{159}$ to the functions of the GCP, the district court con-

${ }^{152}$ See Kessler, 960 F. Supp. at 766.

${ }^{159}$ Kessler v. Grand Cent. Dist. Management Ass'n, 158 F.3d 92, 98 (2d Cir. 1998). The plaintiffs' complaint continued: "Because residents are consigned to a permanent minority status on the Board even though they are numerically superior to the class of owners of property within the district, they are deprived of any meaningful opportunity to advance their interests concerning [GCP] activities." Id.

${ }^{154}$ Id. (listing all of defendants' defenses intended to trigger the Salyer exception).

155 See id. at 104, 108; Kessler, 960 F. Supp. at 774-75.

${ }^{155}$ Kessler, 960 F. Supp. at 771 (quoting Ball v. James, 451 U.S. 355, 363 (1981) (quoting Hadley v. Junior College Dist., 397 U.S. 50, 53-54 (1970))). This is a factual determination; only if the functions have a significant effect on all citizens does the one person, one vote principle apply. See id. (concluding that the Reynolds rule was applied in Hadley because the junior college district was not viewed as a limited purpose governmental body (citing Hadley, 397 U.S. at 53-54)).

${ }^{157}$ See Hadley, 397 U.S. at 53 (listing the trustees' functions as levying and collecting taxes, issuing bonds, hiring and firing teachers, making contracts, collecting fees, supervising and disciplining students, passing on petitions to annex school districts, acquiring property by condemnation, and managing the operations of the junior college); see also supra text accompanying notes $100-05$ (discussing the sufficient general powers finding of the Hadley court).

${ }^{153}$ See Salyer, 410 U.S. at 728-29 (listing the TLB's functions as the acquisition, storage, and distribution of water for farming in the Tulare Lake Basin); see also supra text 
cluded that the GCP served a limited purpose because its services were subject to significant oversight by the City. ${ }^{160}$ The Second Circuit affirmed the district court's decision, holding that the purpose was limited because the GCP's services were: (1) supplemental and secondary to City services; (2) "quantitatively dwarfed by those of the City"; and (3) "qualitatively different from core municipal functions."

There are flaws, however, in the factual and legal determinations relied upon in each court's adjudication of this case. For example, there is less oversight of New York City BIDs than the district court surmised. And, while it is true that the GCP's activities are "dwarfed" by the services provided by the City, its functions are far from limited or unique. Rather, the GCP performs services nearly identical to core municipal functions. Finally, while the services provided may be supplemental to those that the City provides, it is not clear that they affect business owners disproportionately. They may, in fact, create highly undesirable results for GCP residents.

\section{A. Limited Authority/Significant Oversight}

The first inquiry for courts evaluating BIDs is whether the challenged entity is autonomous from the state or city government. If there is no autonomy, then it is part of the government itself, and voters are presumptively protected by the oversight of the duly-elected city or state officials. The issue of oversight is a double-edged sword for BID advocates. On one hand, to serve a "limited purpose," BIDs are forced to argue that they are directly accountable both to their constituencies and to public officials. ${ }^{162}$ On the other, BIDs are successful because of their inherent flexibility and their ability to sidestep the city bureaucracy to accomplish their goals.

accompanying notes 111-16 (discussing the special limited purpose exception to the one person, one vote rule articulated in Salyer).

${ }^{159}$ See Ball, 451 U.S. at 369 (listing the district's functions as the storage and distribution of water, the creation and sale of electrical power, and the hiring of employees, making of contracts, and the acquisition of property to effectuate its water-related duties); see also supra text accompanying notes 117-23 (discussing the extension of the Salyer exception in Ball).

${ }^{160}$ See Kessler, 960 F. Supp. at 773 (citing the various mechanisms the city government may utilize to control the GCP's behavior and noting that the city remained accountable to BID residents).

${ }^{161}$ Kessler, 158 F.3d at 105.

162 See The Grand Central Partnership Response to the Staff Report to the Committee on Finance 5 (Nov. 12, 1997) (on file with the University of Pennsylvania Law Review) ("Grand Central Partnership 'has limited authority over the services it provides." (quoting Kessler, 960 F. Supp. at 773)). 
The Kessler courts upheld the GCP voting scheme based on their conclusion that the GCP had very limited authority and that it was subject to a "high level of municipal control."163 To support these findings, the courts cited two means of accountability: (1) the fact that the GCP "must obtain approval of its plan from the City government before it can act" ${ }^{\$ 164}$ and (2) the existence of four voting Class D board members who are appointed by elected officials and who represent the interests of the City. ${ }^{165}$

The claim that the City exercises significant authority over BIDs is both supported and contradicted by the Giuliani Administration's recent efforts to exercise greater control over the GCP, and by the GCP's inaction in response. In 1998, Mayor Giuliani became increasingly concerned with the growing power of Daniel Biederman, the president of the GCP and of two other contiguous midtown BIDS, ${ }^{166}$ who was widely known as the "mayor of Midtown." 167 Mayor Giuliani charged that Biederman's BIDs were "acting like governments unto themselves" and were turning into private "fiefdoms." the Commissioner of Business Services issued a new directive requiring BIDs to notify the Department of Business Services ("DBS") of all activities, new initiatives, budget changes and contacts with other City agencies. ${ }^{169}$ In what appeared to be either a conflict over the GCP's unwillingness to provide information to the City and its failure to

${ }^{169}$ Kessler, 960 F. Supp. at 773. The court explained that oversight of the BID is significant:

[I]t means that City officials retain accountability to their constituents within the BID. BID residents unhappy with BID activities can always turn to their elected representatives, who, under the statutory scheme, have not abdicated their responsibilities to the BID Board. This safety net is even more apparent when one considers that four Board members are appointed by and represent the interests of City officials.

Id.

${ }^{164} I d$.

${ }^{165}$ See id. (citing the voting power of the Class D directors as a control mechanism on the GCP's authority).

${ }^{166}$ Daniel Biederman was the president of the Grand Central Partnership, the Bryant Park Restoration Corporation, and the 34th Street Partnership. See Thomas J. Lueck, Business Improvement District at Grand Central Is Dissolved, N.Y. TIMES, July 30, 1998, at B1.

${ }^{167}$ See Bidding Biederman Farewell, N.Y. POST, Sept. 24, 1998, at 36 (noting that members of the press had anointed him the "mayor of Midtown").

${ }^{169}$ Id. (internal quotation marks omitted)

${ }^{169}$ See Philip Lentz, Giuliani Directive Puts the Handcuffs on BIDS: Gives Department of Business Services Right To Approve Districts' Activities, CRAIN's N.Y. BUS., Apr. 6, 1998, at 4 ("[M]any BID managers interpreted the new rules as giving City Hall the right to block BID plans before they get off the ground."). 
comply with certain City rules and regulations ${ }^{170}$ or simply "personal pique," the Mayor refused to renew the GCP's contract to manage the BID in July 1998. ${ }^{171}$ The City stated that it would not agree to a new contract until Biederman resigned as president of two of the three BIDs. ${ }^{172}$

While the City's unilateral contract cancellation was legally questionable, ${ }^{173}$ it is telling that the GCP did not respond with a legal challenge against Mayor Giuliani. The GCP's hands were tied. If it argued that the City did not have the right to cancel the contract, it would have conceded that BIDs were in fact the autonomous "fiefdoms" that the mayor complained of. Yet accepting the City's authority to do so would be inconsistent with the autonomy and flexibility that the GCP considers to be the hallmarks of its operations.

The balance of the evidence suggests that the GCP was far more independent than the district court concluded. Even Andrew Manshel, the former General Counsel of the GCP, acknowledged:

We have traditionally had that flexibility which the city government has not had. So, if [the GCP sanitation force] under-runs its budget by $\$ 75,000$ and someone has another nice project they want to do, ... those decisions haven't even risen to the Board level. The president has made [them], usually in consultation with the chairman. In city government, you cannot do that. ${ }^{174}$

Similarly, in a pair of sharply critical reports, the New York City Council Finance Committee found that BIDs were unaccountable in two

${ }^{170}$ See Lueck, supra note 166, at Bl (exploring the DBS's reasoning for refusing to renew the GCP's contract, including general "noncompliance" and "noncooperation"). The City and the GCP engaged in months of negotiations, which were followed by the City's announcement that it would not approve the customary five-year extension of the GCP's contract, but instead would only renew it for one month. See id. at B2.

${ }^{171} \mathrm{~J}$ John Podhoretz, An Ill-Advised Assault on an Urban Visionary, N.Y. POST, Aug. 14, 1998, at 27 (arguing that there was no legitimate reason for Mayor Giuliani to cancel the GCP's contract).

${ }^{172}$ See id. (noting that the rule that a single individual cannot run multiple BIDs undercuts the notion that BIDs are privately run and can independently decide who manages them).

${ }^{173}$ See, e.g., Kessler v. Grand Cent. Dist. Management Ass'n, 158 F.3d 92, 111, 116 (2d Cir. 1998) (Weinstein, J., dissenting) (explaining that the City may not legally withhold assessments it collects on the GCP's behalf and that the City may not dissolve the GCP so long as there exists outstanding debt from GCP-issued bonds). Some raised the possibility that the GCP could challenge the City in court, arguing that it was being denied a "right to operate a public-spirited nonprofit organization." Lueck, supra note 166 , at $\mathrm{B} 2$.

${ }^{174}$ Manshel Interview, supra note 15. 
important respects. ${ }^{175}$ First, once established, BIDs have the potential to exist in perpetuity. Assuming it has no outstanding debt, a BID can be dissolved only by a City Council resolution or upon written petition of owners of at least fifty-one percent of the assessed valuation of benefited real property, and fifty-one percent of the owners of such property. ${ }^{176}$ BIDs cannot be dissolved if they retain an outstanding debt, such as bonds or long term loans. ${ }^{177}$ Second, the City makes little effort to monitor whether benefited property owners wish to continue supporting a BID. ${ }^{178}$ In one of its reports, the City Council charged that DBS is "negligent in its oversight responsibility by failing to monitor and address property owner concerns regarding the overall management and governance of the BID." ${ }^{179}$ DBS may decline to renew a BID contract, but with the exception of Giuliani's action in 1998 , "contract renewal is based on perfunctory hearings and submissions, which do not adequately measure property owner satisfaction." 180

The City has even less control over the GCP's budgeting procedure. The GCP does not need the City Council's approval for its budget if the budget is less than or equal to that of previous years. ${ }^{181}$ The City also may not legally withhold any of the assessments it collects on the GCP's behalf. ${ }^{182}$ The GCP has issued $\$ 32$ million in bonds, which are charged against the City's state constitutional debt limit and for which the City may well be liable in the event of a default. $^{183}$

173 See CIIIES WITHIN CrTIES, supra note 21 (providing a broad analysis of the function and structure of municipal BIDs); FINANCE COMMITIEE, THE COUNCIL OF THE GTY OF NEW YORK, MANAGING THE MrCROPOLIS 7-39 (1997) [hereinafter MANAGING THE MICROPOLIS] (discussing various BID-related concerns in four New York City BID case studies).

${ }^{176}$ See CITIES WrTHIN GITIES, supra note 21, at 18 (arguing that the private dissolution option is preventively expensive).

${ }^{177}$ See id. (noting a BID's ability to issue bonds and accumulate accounts payable).

${ }^{178}$ See id. at 19 ("DBS makes little effort during [a BID's] contract renewal period to determine if there is continued support for the BID.").

${ }^{179}$ MANAGING THE MICROPOLIS, supra note 175, at 32.

${ }^{180}$ CrTIES WTTHIN CTTIES, supra note 21, at 19. As of 1995, DBS had regularly renewed every expired BID contract. Seeid. at I7-18.

${ }^{181}$ See Kessler v. Grand Cent. Dist. Management Ass'n, 158 F.3d 92, 111 (2d Cir. 1998) (Weinstein, J., dissenting).

182 See id.

${ }^{183}$ See id. at 111-12. 


\section{B. General Governmental Powers}

If an entity is determined to have significant autonomy, equal protection analysis requires that a court determine whether it either exercises general governmental powers, or serves a special limited purpose as contemplated by Salyer. In Kessler, the Second Circuit concluded that efforts to provide social services and to improve the physical appearance of the district alone did not transform the GCP into a general governmental body. ${ }^{184}$ The court reasoned that the GCP has a limited purpose because the region is devoted overwhelmingly to commercial use and its goal is to assist property owners to "achieve the remunerative use of that commercial space." The Second Circuit explained that BIDs can still serve a limited purpose even though municipal problems "are necessarily more complex"186 than the agricultural concerns at issue in Salyer.

Salyer did, however, distinguish the functions of a water storage district from traditional governmental functions, ${ }^{187}$ such as housing, transportation, utilities, or roads, and those affecting "quality of life." ${ }^{188}$ The GCP's activities relate to most of these governmental functions. It provides limited housing for the homeless, sets up accessories for the City transportation system (such as bus signs and taxistands), and maintains Grand Central Terminal itself. ${ }^{189}$ It also keeps the sidewalks clean and orderly. Through its supplemental police force, additional sanitation, flower pots, and public events, the GCP's activities are similarly geared to affect the quality of life.

In fact, the GCP's provision of two traditional governmental services-security and homeless outreach programs-has faced substantial public criticism in recent years. In 1995, the New York Times reported that "outreach workers," organized by the GCP to offer referrals for food, shelter, and counseling, were allegedly being sent out as self-described "goon squads" to roust the homeless, to beat them, and to physically force them out of district bank vestibules and plazas and off of sidewalks. ${ }^{190}$ Fervently denied by the GCP, ${ }^{191}$ the incidents

${ }^{184}$ See id. at 104.

${ }^{185} I d$.

${ }^{186} I d$.

${ }^{187}$ See Salyer Land Co. v. Tulare Lake Basin Water Storage Dist., 410 U.S. 719, 72829 (1973).

${ }^{189} I d$. at 729 (noting that the lack of quality of life functions in that case supported the view that the district had limited authority).

${ }^{189}$ See Kessler, 158 F.3d at 105 (describing the GCP's functions).

${ }^{190}$ See Bruce Lambert, 'Goon Squads' Prey on the Homeless, Advocates Say, N.Y. TIMES, 
prompted the Department of Housing and Urban Development to discontinue a half-million dollar grant to the GCP for homeless programs. ${ }^{192}$ The debacle served as a cautionary reminder of the dangers of semi-private entities exercising powers traditionally entrusted to the state.

Even the stated purpose of the BID-improvement of business ${ }^{193}$-is an amorphous goal lacking identifiable limits. Every municipal service affects business in some sense because it affects the welfare of the community. In fact, "the [GCP] is not 'limited' by statute or contract to those activities which directly promote business."194 Critics have argued:

If you can say that [GCP's activities] are business purposes ..., then the City of New York is a business improvement district... and the United States is a business improvement district. Our entire foreign policy is for business purposes. For all the things for the last 20 years that looked inconsistent, like us supporting dictators in Indonesia, and us supporting apartheid, then saying we have trouble with communism because of human rights violations, the one unifying factor is business purposes.... [I] t's all a business improvement district.

Apr. 14, 1995, at B1 (reporting allegations that GCP workers "roughed up homeless people").

${ }_{191}$ Jeffrey Grunberg, the executive director of the Grand Central Partinership Social Services Corporation at the time of the incident said: "It's not true-it's fiction. None of it happened." Id. In an interview in his offices on January 5, 1999, Andrew Manshel, the Partnership's General Counsel at the time of the incident, noted that there were "no hospital records . . . , no police reports of anyone having been injured,... [and] insufficient evidence [for the Manhattan District Attorney] to bring indictments." Manshel Interview, supra note 15; see also MacDonald, supra note 2, at 37 (disputing the veracity of the New Yonk Times report, calling it a "brilliant public relations coup").

${ }^{192}$ See Department of Housing and Urban Development, News Release: HUD Assistant Secretary Andrew Cuomo Cancels Federal Funds to Grand Central Partnership After Investigation Finds Evidence of Brutality Against Homeless People, July 5, 1995 (reporting the decision of HUD to terminate GCP's federal grant). The "goon squad" incident also formed the basis for a lawsuit against the GCP for violations of the Fair Labor Standards Act by providing sub-minimum wages to the outreach workers. In Archie v. Grand Central Parinership, Inc., 997 F. Supp. 504, 507-08 (S.D.N.Y. 1998), a federal district court held that the Partnership unlawfully paid "goon squad" workers sub-minimum wages to perform clerical, administrative, maintenance, food service, and outreach work. Despite the GCP's contention that the "workers" were participants in a jobtraining program, and were thus not entitled to minimum wage, the court found for the plaintiffs in the action. See id.

${ }^{193}$ See Kessler, 158 F.3d at 94 (stating that BIDs are "intended to promote business activity").

${ }^{194}$ Id. at 126 (Weinstein, J., dissenting).

195 Interview with Douglas Lasdon, Executive Director of the Urban Justice Center, in New York, N.Y. (Jan. 5, 1999). Mr. Lasdon was one of the plaintiffs' attorneys of re- 
The breadth of "business improvement" suggests that the lines drawn by the Kessler courts may be inconsistent with the Avery and Hadley decisions, where the Court held that the principle of one person, one vote must apply. ${ }^{196}$ The governmental functions performed by the GCP appear to be at least as broad as the Commissioners Court in Avery and the junior college district in Hadley, both of which failed the "special limited purpose" prong of Salyer. ${ }^{197}$

\section{Disproportionate Impact}

The Kessler courts' analysis of the disproportionate impact of the GCP's voting scheme is also worthy of greater scrutiny. This prong of the equal protection inquiry focuses on whether the challenged voting classification is supported by a "genuine difference in the relevant interests" of those enfranchised and those denied an equal political voice. $^{198}$ In its Kessler opinion, the Second Circuit stressed that Salyer does not require that the selected class of voters for limited purpose entities be the only parties affected. ${ }^{199}$ The court held that the proper inquiry is whether the effect of the operations on property owners was "'disproportionately greater than the effect on those seeking the vote. $" 200$

Under the GCP voting scheme, there are two relevant effects. Viewed through a proprietary lens, ${ }^{201}$ the first is the burden of the assessment to support the BID, which clearly falls disproportionately on property owners. While non-property owners may be burdened indirectly through leases that reflect the cost of the assessment, ${ }^{202}$ "there is

cord in both the Kessler and Archie challenges.

${ }^{196}$ For a detailed discussion of the governmental functions at issue in Avery and Hadley, see supra text accompanying notes 69-82, and 100-06. But see Ball v. James, 451 U.S. 355, 370 (1981) ("Nothing in the Avery, Hadley, or Salyer cases suggests that the volume of business or the breadth of economic effect of a venture undertaken by a government entity as an incident of its narrow ... function can . . . subject the entity to the one-person, one-vote requirements of the Reynolds case.").

${ }^{197}$ See Ball, 451 U.S. at 370 (" $[\mathrm{A}] \mathrm{n}$ aspect of that limited purpose is the disproportionate relationship the Districts' functions bear to the specific class of [voters].").

${ }^{198}$ Lockport v. Citizens for Community Action at the Local Level, Inc., 430 U.S. 259,268 (1977) (setting forth the second branch of equal protection analysis in similar voting schemes).

${ }^{199}$ See Kessler, 158 F.3d at 108.

${ }^{200}$ Id. (quoting Ball, 451 U.S. at 371).

${ }^{201}$ See Briffault, supra note 83 , at 371 (explaining the "proprietary model's method of assessing impact").

${ }^{202}$ See Kessler, 158 F.3d at 107 ("[S]ome property owners who lease their property to others may seek to pass all or part of the cost of the assessment to their tenants . . . by raising rents."). 
no way that the economic burdens of district operations can fall on residents qua residents." ${ }^{203}$ Viewed through a democratic lens, ${ }^{204}$ the second effect is the impact of BID services on those who reside within the BID's territories. It is far less clear that this effect falls disproportionately on the property holders.

BIDs may impact non-property-owning residents by having significant influence on city governance as a whole. The property owners within the GCP who own some of Manhattan's most valuable property are, by definition, among the most wealthy people in New York. They provide a significant portion of the City's tax base, and, because of their prominence, they have greater access to elected officials and significant opportunity to influence them. These property owners have an incentive to lobby the City to decrease the general City tax because they do not want to pay for City services twice. ${ }^{205}$ According to Robert Solomon, who represented the plaintiffs in Kessler, "if the city currently has a revenue pie of 100 pennies ... and the BIDs self-tax, raising the pie to 110 pennies, they get to keep all those additional pennies and will pressure the city against the tax increase." ${ }^{206}$

Economist Moshe Adler cites the City's actions during the 19921993 fiscal crisis as an example of BIDs' influence on larger City policy. ${ }^{207}$ During the crisis, the City fired hundreds of sanitation workers and reduced the number of machine-driven street cleaning days from six to four. ${ }^{208}$ Adler charges that as a result of the proliferation of BIDs, "no pressure [was] coming from the city's most influential citizens, and the former street-cleaning schedule was never restored." ${ }^{209}$ Such self-interested pressure from powerful groups could have a devastating impact on poorer sections of the City. As explained below, this pressure actually might create damaging results for non-propertyowning residents within the GCP's territory.

${ }^{203}$ Id. (quoting Salyer Land Co. v. Tulare Lake Basin Water Storage Dist, 410 U.S. 719,729 (1973)).

${ }^{204}$ See Briffault, supra note 83 , at 371 (noting that this view utilizes "an expansive definition of economic impact").

${ }^{205}$ Commercial tenants in another New York City BID, the Madison Avenue BID, recently wrote to the mayor to ask why they should have to "contribute toward services that the city is already responsible for providing and for which they were already paying taxes." Moshe Adler, Why BID's Are Bad Business, N.Y. TIMES, Feb. 13, 2000, $\S 14$, at 17.

\footnotetext{
${ }^{206}$ MacDonald, supra note 2, at 41.

${ }^{207}$ See Adler, supra note 205.

${ }^{203}$ See id.

${ }^{209} I d$.

${ }^{210}$ See discussion infra Part II.C.2.
} 
BIDs also affect non-property-owning residents by operating in direct competition with the City on a broader scale. Under New York law, in any given year, a municipality only can raise a limited amount of its revenues from taxes on real property. ${ }^{211}$ BIDs levy an assessment on all property owners within their districts, which is included in the total amount the City of New York is permitted by law to raise. ${ }^{212}$ The inevitable result is that the City has a lower limit when raising discretionary taxes, thereby decreasing its ability to provide other City services.

In that vein, BIDs also have the statutory authority to float bonds to pay for their more substantial improvements. Pursuant to state and City law, the GCP has issued bonds totaling approximately $\$ 32$ million dollars. Interest payable on these bonds is tax exempt. ${ }^{213}$ By authorizing BIDs to issue bonds, the City faces additional competition in the bond market among those seeking to support local bond issues. ${ }^{214}$ Notably, the GCP has earned a higher rating on its bonds than has the City of New York in recent years. ${ }^{215}$ Since its bonds have received a lower rating, the City is forced to offer a higher rate of interest in the bond market than the GCP. Thus, the GCP bonds present a lower-risk alternative than do New York City bonds, particularly for those investors wishing to support local bond issues while pursuing a more riskaverse portfolio.

\section{Providing Public Goods to City Residents}

The broader effect of BIDs on non-property-owning residents can best be demonstrated by an analysis of the distribution of public goods. A municipality's primary function is "to provide local public goods," ${ }^{216}$ which have two defining qualities. First, they are nonrivalrous, meaning that the consumption of a public good by one person does not leave less for anyone else. ${ }^{217}$ Second, they are nonexcludable,

${ }^{211}$ See N.Y. GEN. MUN. LAW § 3-b (McKinney 1999) (setting forth the limits on the amount to be raised by tax on real estate in any fiscal year).

212 See id.

${ }^{213}$ See Kessler, 158 F.3d at 111 (Weinstein, J., dissenting) (noting GCP's bond issuance and its characteristics).

${ }^{214}$ See id. at 111-12 (stating that the issuance of GCP bonds reduce "the amount of money that the City can raise through its own future bond issues").

${ }_{215}$ See MacDonald, supra note 2, at 34 (noting that in 1992 and 1993 the GCP's bonds received a credit rating of $\mathrm{Al}$, "far higher than the city's").

${ }^{216}$ Ellickson, supra note 41 , at 88.

${ }^{217}$ See COOTER \& ULEN, supra note 16, at 42 (defining the nonrivalrous consumption quality of public goods). 
which means that no private profit-maximizing enterprise would supply them because the cost of excluding nonpaying beneficiaries is too high. $^{218}$ Public goods include commodities like those offered by BIDs-sanitation services, police protection, and limited aesthetic improvements.

As an example, Cooter and Ulen discuss a city block that is plagued by crime, prompting some residents to propose hiring a private guard. ${ }^{219}$ Many residents contribute to this venture voluntarily, while others refuse. This creates a danger that paying residents would "instruct the guard not to aid nonpayers in the event of a mugging." Even so, the very presence of a private guard would make the street safer for everyone, because "muggers are unlikely to know who has and who has not paid for the guard's services. ${ }^{221}$ Thus, there is no effective way for payers to compel nonpayers to contribute, and the nonpayers enjoy a free ride. ${ }^{222}$

It appears from the example above that the Kessler plaintiffs are free riders-they pay disproportionately low assessments, but ostensibly reap a high marginal benefit. One might suspect that the residents and business owners have matching incentives to improve the quality of life in the district. The improvements made in the Grand Central area arguably are those that residents should expect from an optimally-performing government. Accordingly, if there were no difference in priorities between the residents and businesses, then it would have been irrational for the GCP to have expended time and resources to fight the lawsuit. A brief illustration, however, suggests that such matching incentives may not exist. ${ }^{223}$

\section{Negative Net Benefit}

Consider a hypothetical situation in which the 920 residents and businesses within the GCP might have dissimilar interests. Assume

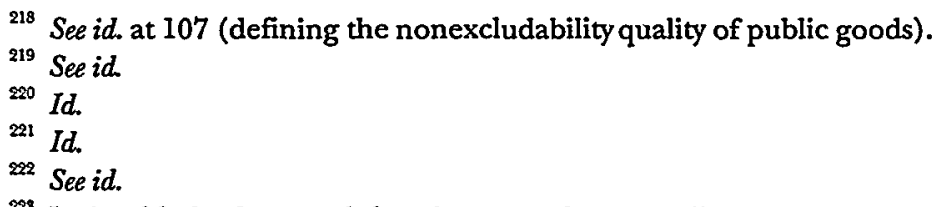

${ }^{223}$ It should also be noted that there may be some divergence in interest between the owners of real property and tenants pursuant to leases of commercial space within the GCP. A prime example occurred upon the formation of another New York BID, the Downtown Alliance BID. The city created the BID, then announced a plan to change zoning to allow offices in the district to be converted into apartments. See Adler, supra note 205. The conversions benefited landlords, but to commercial tenants, the zoning changes were "a calamity." Id. 
that the businesses, which have formed a partnership, are interested in a strong police presence for their clients and customers only during business hours. Also assume for the purposes of this discussion that residents of the area want high police levels especially in the evening hours, upon returning home after businesses have closed for the day. ${ }^{224}$ In the absence of a BID, the City of New York may provide a constant level of police protection (whose value equals ten units) during the entire twenty-four hour period (five in the day, five at night). This serves the interest of the businesses who want their clientele to feel safe during the day, as well as the interest of residents, who spend more time in the area in the evening hours. A properly functioning general city government would seek to respond to the needs of both the business and residential communities.

Then, introduce a BID. A BID such as the Grand Central Partnership, in which property owners have a controlling interest, may decide to provide increased police services itself during the Monday to Friday business hours (with an additional value of three units), but not at night. This preference is commensurate with the interests of the property owners, since they are the ones who rent space to the businesses in the region. The result is that during the daytime hours, there are now eight units of police protection (five units from the City and an additional three from the BID). Since the BID chooses not to add units at night, the police protection from the City remains constant at five.

Let us estimate that each resident pays $\$ 100$ per year for the administration of the $\mathrm{BID},{ }^{225}$ and that the value to the resident of the additional three units of police protection is only $\$ 50$, since the resident spends little time in the BID area during daytime hours. Since the marginal benefit to the resident of gaining the three police officers during the day $(\$ 50)$ is less than the levied cost $(\$ 100)$, the resident will be worse off for having contributed to the BID administration. There is both a positive benefit ( $\$ 50)$, and a positive cost $(\$ 100)$,

${ }^{224}$ The specific circumstances of this hypothetical situation would not exist in the territory of the GCP because the police provided by the BID do not have the same coercive powers as those of the New York City Police Department. Yet, it serves to illustrate a situation in which there are not matching incentives. It could play itself out in decisions whether to incur greater debt, long-term structural improvements, and the area of many government services, including sanitation or social welfare programs.

${ }^{225}$ In reality, residents do not pay any additional taxes directly to the GCP. See Kessler v. Grand Cent. Dist. Management Ass'n, 158 F.3d 92, 107 (2d Cir. 1998). The Second Circuit recognized, however, that it was possible that "part of the cost of an assessment would be passed on to resident nonlandowners." Id. 
but the positive cost outweighs the positive benefit in this case. If, however, the BID chooses to increase police at night (an unlikely event considering the composition of the Board and the likely preferences of commercial property owners), the benefit to the residents would outweigh the costs. Similarly, if the residents are not forced to provide any funds directly or indirectly to the BID, they will be better off because more public goods (i.e., three extra units of daytime police) are better than fewer, all other things being equal.

\section{Government Changes Its Basic Services}

As explained above, there is a danger to BID residents that government will change its services in response to BID lobbying, or that it will decrease its services voluntarily, free riding on the BID's provision of services. In both situations, the Kessler plaintiffs might be affected simply because they have little representative voice.

BIDs are an exercise in collective action. ${ }^{226}$ Once BIDs are formed, they are hard to disband, and the BID rationally will use its influence to achieve maximum benefits for the narrow interest of the represented members. As a practical matter, a BID contract comes up once every five years ${ }^{227}$ and only can be dissolved if it retains no debt. ${ }^{228}$ Because BIDs conceivably could exist in perpetuity, the use of a BID's collective voice to lobby the city government creates a real danger to the minority (in this case, residents).

Assume, as above, that ex ante the City allocates ten units of law enforcement daily-five during the day and five at night. The BID rationally might use its influence, for example, to ask the City to change its policy and reallocate seven of those units during the day, leaving only three at night. Again, the BID might decide independently to pay for three more daytime units of police, bringing the total to ten units during the day. Since the BID has less incentive to provide police at night, it likely will not allocate resources to night protection, even though the City's allocation has dropped to only three nighttime units. This will result in a "public bad" for residents. In the absence

${ }^{226}$ See MANCUR OLSON, THE LOGIC OF COLIECTIVE ACTION: PUBLIC GOODS AND THE THEORY OF GROUPS 9-16 (1971) (describing the connections among lobbying, collective action, and governmental responsibility).

${ }^{227}$ See Kessler, $158 \mathrm{~F} .3 \mathrm{~d}$ at 95 (stating that contracts are "subject to renewal for a fiveyear term at the 'sole discretion' of the City" (citation omitted)).

${ }^{223}$ See Kessler, 158 F.3d at 116 (Weinstein, J., dissenting) ("The City does not possess the power to dissolve the [GCP] or a successor because the [GCP] has issued bonds and remains financially obligated to satisfy its outstanding debt."). 
of the BID, the residents had an even distribution of five units during the day and five at night. Now, in the aggregate, they have thirteen, but their preferences are not reflected-they have only three at night, whereas they had five prior to the lobbying effort by the BID. Even if they do not contribute to the BID revenues, they are worse off. They do not have the safety provided in the hours they want, and even the duly elected city government neglects their wishes as a result of the BID's successful lobbying efforts.

If, in the alternative, the government simply reduces its allocation of funds to the area because of the BID's existence, it becomes a free rider on the BID's services. ${ }^{229}$ This is particularly problematic for the residents, whose preferences are not reflected by a board structurally favoring property owners. In this scenario, the BID is dictating the governance of the area, while the one entity protected by the democratic, one person, one vote principle, the city, abdicates all control.

A fundamental problem exists with the structural majority representation of property holders on the Board of Directors of the GCP. All residents must pay an assessment, albeit small, without the ability to exercise a majority vote on the Board. In his Avery dissent, Justice Fortas argued that votes should be doled out, as in the corporate shareholder context, in proportion to the number of shares possessed. $^{230}$ The problem with this analogy is that all corporate shareholders have the same incentive-to maximize profits-whereas the incentives in the BID context seem to vary significantly. As group preferences concerning the allocation of resources within a BID diverge, the minority status of contributing members may lead to unjust results. Residents may be forced to contribute to an arrangement which, in the end, leaves them worse off.

\section{CONCLUSION}

BIDs can provide an extremely effective and attractive alternative to traditional government. Supporters assert that if all BIDs were to cease operations tomorrow, "it is fanciful to think that New York would revamp its work rules, civil service policies, and spending priorities fast or fully enough to prevent further business decline. Forcing

${ }^{229}$ See, e.g., MacDonald, supra note 2, at 42 ("We are all free riders on BID expenditures.").

${ }^{230}$ See Avery v. Midland County, 390 U.S. 474, 507 (1968) (Fortas, J., dissenting) (comparing the electoral plan for the Midland County Commissioners Court to the standard of corporate decency). 
businesses to die a slow death in order to highlight the City's failings is unlikely to refocus its priorities." ${ }^{\text {231 }}$ If we concern ourselves with individual rights, such as equality principles in voting, "the city goes bankrupt .... You have to do what needs to be done to see that the city survives." ${ }^{232}$

BIDs should be preserved because of their success in solving complex municipal problems. Pointing out the constitutional flaws with the Kessler decision, and the rationality of the plaintiffs in bringing the suit, is not intended to minimize the value of BID-provided services. Yet recognizing the positive results of BIDs does not change the fact that the operations of the Grand Central Partnership are not limited in the factual sense anticipated by the Supreme Court in Salyer and Ball.

Salyer and Ball create an exception to the strict scrutiny ordinarily applied to any restrictions on the right to vote. The exception is narrow-even by definition-applying only where a district serves a "special limited purpose" with a disproportionate effect on those afforded the right to vote. The Supreme Court has given limited guidance to lower courts in their efforts to construe this doctrine, and has forced them to conduct factual inquiries analogizing challenged districts, for example, to the water storage and electrical districts in Salyer and Ball, the junior college districts in Hadley, and the Commissioners Court in Avery. Amidst this confusion, those courts have produced inconsistent results.

The Second Circuit evaluated the Kessler challenge in this context. The court considered the GCP and saw a semi-private entity that levied an assessment on a small group of property holders to provide limited services that affected those individuals disproportionately. The City creates the BIDs, collects their assessments, and redistributes them to the management association-all of which suggest a fair amount of municipal control. The services they provide are arguably de minimis, in the form of street-sweepers, flower pot holders, and uniform street signs.

The power of BIDs, however, is not limited to the simple services they provide. The GCP board is comprised of powerful and influential people, and its success largely is due to its ability to provide sanitation and security services, and make capital improvements quickly, efficiently, and without municipal interference. The BIDs' ability to

${ }^{291}$ MacDonald, supra note 2, at 41.

${ }^{232}$ Id. at 40. 
lobby and influence broader City policies is not quantifiable, but it is worth considering. The potential to have such an impact (albeit mostly positive) on City residents both within and without the BID raises the specter of whether "business improvement" was contemplated by the Supreme Court when it set forth the "limited purpose" exceptions in Salyer and Ball. Until the Supreme Court examines this question, however, lower courts are left with little precedential guidance in determining whether a BID's governmental purposes and disproportionate effects trigger the constitutional requirement of "one person, one vote." 